\title{
The Influence of Export Diversification on Economic Growth: A Case of Southern African Development Community (SADC)
}

\author{
Espoir Lukau Matezo ${ }^{* \#}\left(\mathbb{C}\right.$, Benjamin Mwadi Makengo ${ }^{2}\left(\mathbb{0}\right.$, Amantha Malimingi Muhole $^{3}(\mathbb{C})$ \\ ${ }^{1}$ School of Economic, Hefei University of Technology, Hefei, China \\ ${ }^{2}$ School of Politics and International Studies, Central China Normal University, Wuhan, China \\ ${ }^{3}$ School of Management, University of Science and Technology of China, Hefei, China \\ Email: ^hopelukau@gmail.com, benjaminmwadi@yahoo.com, malimingiamantha@gmail.com
}

How to cite this paper: Matezo, E. L., Makengo, B. M., \& Muhole, A. M. (2021). The Influence of Export Diversification on Economic Growth: A Case of Southern African Development Community (SADC). American Journal of Industrial and Business Management, 11, 829-845.

https://doi.org/10.4236/ajibm.2021.117051

Received: June 11, 2021

Accepted: July 23, 2021

Published: July 26, 2021

Copyright $\odot 2021$ by author(s) and Scientific Research Publishing Inc. This work is licensed under the Creative Commons Attribution International License (CC BY 4.0).

http://creativecommons.org/licenses/by/4.0/

\begin{abstract}
The paper assessed "the influence of export diversification on economic growth in SADC". GMM approximation technique was adopted to obtain reliable approximations of the effect of export diversification on economic growth. Our study accounts for time-series variations in the data, captures country-specific time-invariant effects, and controls for endogeneity in the estimation model. The results show a significant effect of constructs of export diversification on economic growth. In addition, the study indicates a significant result on the additional control variables such as (human capital, domestic capital, and foreign direct investment). Based on findings, the paper recommended that governments in SADC should promote export diversification and investment in both physical and human capital, keep political stability under control, and set policies that will fascinate foreign direct investment into enhancing productive sectors of their national economies.
\end{abstract}

\section{Keywords}

Initial Real GDP Per Capita, Human Capital, Physical Domestic Capital, Foreign Direct Investment, Export Diversification Squared

\section{Introduction}

The concentration of African economies on highly sensitive to international price fluctuations and the export of a few traditional primary exports seems to be prominent between the various causal factors (Cook \& Jones, 2015; Hamed, Hadi, \& Hossein, 2014; Ross, 2019). Dependence on a thin range of exports results

${ }^{\#}$ First Author. 
in risks related to the lack of diversification, therefore, increasing a weakness of country to international economic jolts. The purpose of diversification is to alleviate these threats, including instability and volatility in export retributions, which then exert opposing effects on development and growth, investment, employment planning, foreign exchange reserves, export capacity, inflation, capital flight, and debt repayment (McNown, Sam, \& Goh, 2018). Deprived growing and development performance were one of the main problems challenging many countries of $\mathrm{SADC}^{1}$ for a long time. And it has drag researchers attention who sought to clarify the conceivable reasons for the pretty miserable economic performance of SADC Nations over the years. This study intends to make inquiries whether export diversification is considered in the physical transformation method.

However, there are certain suggested effects of export diversification on economic growth and competitiveness; there is no arbitrary conclusion about the existence and type of correlation between these two variables (Garcia, Ciko, Gaurav, \& Hough, 2015; Hesse, 2009). This study pursued questions that arise on the specific relationship between export diversification and economic growth and how it affects SADC member states' competitiveness in the international market. The study determines the role of export diversification on economic development in the SADC context. This study will help policymakers, traders, the government, and the whole business public to know to which extent and the role played in the effect of export diversification on the economic growth and competitiveness of the country's economy. It will also help policymakers on which approach to implement when it comes to international trade.

Apart from this introductory section, the rest of this present paper is organized as follows. The second section is devoted to the literature review. The third and fourth sections will separately set out the methodology and present the empirical results, thus making it possible to identify the main factors contributing to the diversification of exports in SADC countries. The fifth section presents the results and discussions. And finally, the last section concludes and makes some valuable recommendations.

\section{Literature Review}

Economic growth has been a key theme of concern for states and economists. The impression that export diversification (ED) persuades economic development and growth is not strange to the progress of economic theories. In a wide-ranging sense, diversification may be understood as an alteration in the conformation of an economy's current export structure. (Umarxodjaeva \& Sa-

${ }^{1}$ The Southern African Development Community (SADC) has existed since 1980 as a loose alliance of nine majority Southern African states, known as the Southern African Development Coordination Conference (SADCC), with the main purpose of coordinating development projects to reduce economic dependence on the then apartheid South Africa, whose members are: South Africa, Swaziland, Tanzania, Zambia, Angola, Botswana, Madagascar, Malawi, Mauritius, Democratic Republic of Congo, Lesotho, Mozambique, Namibia, Seychelles, and Zimbabwe. 
driddinova, 2019) looks at diversification in export as a course of spreading the variety of products to be exported in a country. It may be mentioned as the feast of production of a country and exports over various sectors.

Literature shows that productive systems suffered significantly from high trade barriers and distorted relative prices (Arip, Yee, \& Abdul Karim, 2010). In light of this, structuring new comparative advantage in new and non-traditional exports, including labor-intensive manufactures, still ruins a critical objective for small economies. Industrial exports are believed to support constant overall economic growth for numerous reasons. The major reason is that the demand for factory-made goods increases more with income rises than the demand for main products. Therefore, growth prospects for a nation's exports are higher by specializing in the industry. Policymakers might use export diversification as a source of economic growth in cases where the national market size is small (Umarxodjaeva \& Sadriddinova, 2019).

In light of these circumstances, Iizuka \& Gebreeyesus (2017) agrees on the view that divergence into non-traditional exports opens up new occasions and new markets for businesses. More so, Kahiya (Kahiya \& Dean, 2016) posit that old-fashioned exports are greater at risk from exogenous tremors leading to limited demand owed to their low-income elasticity and declining terms of trade. It is widely accepted that developing countries should use outward-looking strategies in their changeover toward appearance. East Asian tigers have observed tremendous and sustainable exports, as have emerging countries like Chile, Tunisia, Botswana, and Mauritius (Liu, Kim, Liang, \& Kwon, 2018). Even fast-growing countries like China and Brazil have relied on world markets (Liu et al., 2018). Exporting allows firms in developing countries to expand their markets and profit from economies of scale. Furthermore, through exports, a country may create foreign exchange earnings, increase productivity, and increase employment, promoting economic growth (Iizuka \& Gebreeyesus, 2017).

In SADC, data demonstrate that the export annual growth rate was optimist during the 1984-2015 period, mostly due to higher prices on world markets and the rise of gold (Garcia et al., 2015). Nevertheless, the preceding observations and the effect of export diversification on economic growth in the Southern African Development Community (SADC) have not conventionally cared.

Southern African Development Community regional economic community consisted of fifteen (15) member states geographically lying in southern Africa and was established as a coordinating development conference (SADCC) in 1980 (Garcia et al., 2015). Most Southern African nations are allied with low and unstable growth in the face of a great occurrence of poverty. And we all know that poverty is not good in commodity basket of a country, and according to Hesse, the poverty cannot be alleviated or eradicated in isolation (Hesse, 2009). The clue has been showing that diversification can lead to upper growth. Nonetheless, this assertion has mainly remained theoretical over the years from the time 
when empirical literature elucidating growth that could be encouraged by diversification is rare, particularly in the case of SADC.

It is detected starting the writings that the export carriers of developed countries encompass high value-chain merchandises whereas that of developing countries; mainly those in SADC, mostly crop and export basic goods but with low value-added products (Garcia et al., 2015). The fiscal theory proposes that qualified to agricultural (primary or basic), manufactured products and article of trade prices are disposed to intrinsic world market volatilities (Garcia et al., 2015). Also, the emergence of artificial substitutes has additional excavated the afflictions of the exporters of prime goods by relocating them as transitional efforts (Yokoyama \& Alemu, 2009). Following in a similar analogy, Jutting Johanne (Jütting et al., 2004) perceived that still, Africa's economies shortage the necessary "shock absorbers" to endure shocks either internal or external. Thus, the fact may be innovative that effort of Africa at raising the economic tallness has been partially crippled by extraordinary dependence on a few prime commodities. SADC has been measured the deprived area in the world and the only constituency where parsimonies are festering; half of its inhabitants live on less than one dollar per day; and life expectancy is falling (Garcia et al., 2015). Due to that insight, additional measures were projected to provide more stimulus to export manufacturers (Hesse, 2009).

And as already pointed out in passing above, in the existing literature, governance, access to markets and finance, investment, human capital, fiscal, trade and industrial policies, exchange rates and inflation, and external balances-to name but a few, are variables that many scholars often use more, trying to study how they affect economic growth. But rather, export diversification is not often supported by the existing literature of empirical studies. This is a gap that this study attempts to fill. As well, the most advanced existing empirical studies of the influence of export diversification on economic growth often do not take into account not only time series variations in the data, the capture of unobserved country-specific time invariant effects, and the control for endogeneity in the estimation model, but also the combination of the political stability variable with other variables. Moreover, there are also no specific empirical studies for the SADC case. The gaps that this paper tries to fill, by proposing itself here to determine the likely relationship between export diversification and economic growth, demonstrating the possible influence of the first on the second. Thus, its specific objectives are:

* To study the effect of export diversification on economic growth in SADC.

* To test hypothesis of a hump-shaped correlation between diversification of export and economic growth for SADC.

* To Figure the Critical Diversification Index for SADC if a hump-shaped correlation exists between variables of this study.

* To define the strength and course of the correlation between export diversification and economic growth in SADC. 
This paper used the Heckscher-Ohlin theory this theory argues that a country can only gain from international trade if it specializes in the production and exportation of the product basing on its comparative advantage (Kalayci, 2019). The unity of countries in international trade are bright to consume and produce yonder the initial levels of their PPFs (Production Possibility Frontiers) and indifference curves based on specialization. It's, therefore, follows that export diversification comes naturally to countries endowed by many production resources with other nations.

Hypothetically, there are numerous ways through which export diversification encourages economic growth. According to Wang et al. (Wang, Chang, Rizvi, \& Sari, 2020) export diversification can positively affect economic growth by falling the dependency on a limited number of merchandises. This argument is predominantly true in terms of commodity-dependent developing countries, where overdependence on the agricultural sector might reduce trade terms. Due to Hesse (Hesse, 2009), the elementary reason for this is the high price volatility of commodity merchandise.

Another way of clarifying export diversification's dynamic effect on growth is by linking the connection between these two variables based on modern theory vis-à-vis the classical trade theory. Based on the modern trade theory, there are three main features of modern market behavior. First, the swelling dynamic features of production factors and national policies affect the production capacity to rise with increasing return. Second, the enlargement of the trade model from perfect competition to imperfect competition, especially the autocratic competition. It is partially linked to the first factor. The increasing intensity of trade liberalization amongst nations and the mobilization of production factors have enabled firms in one country to expand their production without being constrained by diminishing returns (Umarxodjaeva \& Sadriddinova, 2019). This argument, in contrast to the classical trade theory, implies that they could involve in various production activities without confining to their comparative advantage (Wang et al., 2020).

While the two factors as mentioned earlier explain the supply side's market behavior, the third characteristic of modern trade theory is the demand side. It is reflected by domestic market peculiarities across different countries, which are not fixed and vary in various aspects such as taste, average income, knowledge, gender, age, culture, and geographical division. While production in each particular country tries to meet unique characteristics of domestic market demand, it also enters symmetrically into the international market demand. Subsequently, it offers the market with goods and services, which are different in the form of functionalities, taste, design, ingredient, quality, and appearances. According to Ross (Ross, 2019), a country tends to export those goods for which they have a relatively large domestic market.

IRGDP per Capita: Let us look in a dynamic panel model, the constant of the draped dependent variable dealings the level of rapidity of change. A virtuous 
reason for presenting this inconstant as a regressor is to rheostat for description prejudice and account for the perseverance in Real Growth Domestic Product per Capita Growth. As of the theory of convergence, it is predictable that the constant of this variable would remain negative. According to Robinson et al. (2017), export diversification can be considered into two categories: the horizontal and vertical diversification. The earlier refers to the diversity of products across different categories of industry, while the latter shelters diversity of products within the same industry. Both types of diversification are projected to persuade economic growth positively (Robinson, Hammitt, Chang, \& Resch, 2017).

Human Capital: (Han \& Lee, 2020) suggest that by human capital affect domestic income growth correspondingly that increasing personal human capital crops personal income growth. Mincer further claims that the involvement of human capital to economic growth far-off dwarfs that of physical investment.

Foreign Direct Investment (FDI): Based on the literature on foreign direct investment growth relationship provides contradictory theoretical forecasts concerning the effects of Foreign Direct Investment on economic growth and development. It is broadly recognized that the movement of FDI has been swelling for a long time, and developing countries are especially applying FDI-inducing strategies to attract foreign investment (Han \& Lee, 2020). It is supposed that technical transmissions and spillovers go together with Foreign Direct Investment flows. Meanwhile, there is a prevailing gap between developing and developed nations, that gaps could be connected through FDI flows.

Export Diversification Squared: The export diversification squared is encompassed in the estimation model to capture the possible non-linear relationship between export diversification and economic growth in SADC. When a non-linear correlation is predictable between ED and RGDP per capita growth, we anticipated the constant of this variable to be negative. The SADC's critical diversification index (CDI) would be figured subject to the sign of a hump-shaped correlation flanked by growth and export diversification (Hesse, 2009).

Political stability: A study of the impact of political instability on economic growth needs to deal with the tricky of joint endogeneity. Even if it is true that a high propensity of having recurrent government changes reduces growth, it may also be the case that low growth raises the probability of a government change. The effect of evolution on government changes is expected to be observable in both dictatorships and democracies. In democracies, the vast empirical literature has established that high growth in pre-election years increases the incumbent government's likelihood of reelection: voters do not reelect incumbents if they perceive that the latter have mismanaged the economy (Kalayci, 2019).

Regional dummies: The regional dummies are presented hooked on the approximation equation to regulate whether significant differences occur amongst the various regional slabs of SADC concerning the explanatory variables' effect on economic growth. The regional dummies are for the Central, Southern, East and West of Southern Africa development community. 


\section{Methodology}

\subsection{Data Description and Source}

The subsequent explanatory variables are included in this study which is reflected as essential for economic growth in SADC (see Table 1).

These variables are Human Capital, Initial Real GDP per Capita, Foreign Direct Investment (FDI), Physical Domestic Capital, Export Diversification Squared, Political stability, Regional Dummies, and Interrelated Variables ED with the Regional Dummies. These variables are deliberated to ensure clauses, focusing on their predictable correlation with Real GDP per Capita growth and their substitutions. Entire data on all the variables are obtained from the World Development Indicators (WDI) by Online Database of the World Bank, 2018.

\subsection{The Model Specification}

Export diversification is a particularly suitable development strategy in the first stages of economic development (Cadot, Carrère, \& Strauss-Kahn, 2011). The study uses panel data on fifteen (15) SADC countries for 1998-2018, for which consistently sufficient data are available. Data for each variable of this study used for the analysis is taken out from the Online Database of the World Bank's World Development Indicators (WDI), 2012. Data on export diversification was obtained from the International Monetary Fund (IMF).

This paper considers the SADC data when the SADC is in the second stage of the export product basket (export concentration). Note that when diversification declines in SADC exports, the country becomes less diverse and hence more concentrated, as contended by Cadot (Cadot et al., 2011).

Based on the dynamic panel Equation (2) and subsequent (Williams, Allison, \& Moral-Benito, 2018) and (Hesse, 2009); with few alterations centered on the explanation of the variables under study, the model to be assessed is hence written as:

$$
\begin{aligned}
R G P C G_{i t}= & +\alpha_{1} I R G P C_{i, t-1}+\alpha_{2} E D_{i t}+\alpha_{3} E D_{i t}^{2}+\alpha_{4} G S S E R_{i t}+\alpha_{5} P D C_{i t} \\
& +\alpha_{6} F D I_{i t}+\alpha_{7} P S_{i t}+\alpha_{8} \sum_{1}^{4} D_{i}+\alpha_{9} \sum_{1}^{4} E D^{*} E D_{i}+V_{i t}
\end{aligned}
$$

where: $R G P C G_{i t}$ is real GDP per capita growth, $I R G P C_{i t}$ is initial real GDP per capita; $E D_{i t}$ is the index of export diversification; $E D_{i t}^{2}$ is term squared of the index of export diversification; $G_{S S E R_{i t}}$ is gross secondary school enrolment rate (a proxy for human capital); $P D C_{i t}$ is physical Domestic Capital; $F D I_{i t}$ is the foreign direct investment as a percentage of GDP; $P S_{i t}$ is political Stability, $D_{i}$ means dummy for four regional; East, Central, Southern and West of Southern Africa;

$E D^{*} D_{i}$ is the product (interface) of export diversification index and the country dummies; $V_{i t}=$ Idiosyncratic error term.

The Critical Diversification Index is derivative by setting the partial derivative of real GDP per capita for the index of ED to zero from Equation (3). The CDI shows the point at which a turnaround in real GDP per capita arises to export diversification. 
Table 1. Data description and source.

\begin{tabular}{ccccccc}
\hline Region & $\begin{array}{c}\text { Human capital } \\
\text { (Population } \\
\text { rate) }\end{array}$ & $\begin{array}{c}\text { FDI, net } \\
\text { inflows } \\
\text { (of GDP) }\end{array}$ & $\begin{array}{c}\text { GDP/capita GDP/capita } \\
\text { constant }\end{array}$ & $\begin{array}{c}\text { Gross fixed } \\
\text { growth } \\
\text { capital }\end{array}$ & $\begin{array}{c}\text { Political } \\
\text { stability }\end{array}$ \\
\hline East of SA & 82.3 & 2.1 & 4006.54 & 2.6 & 26.5 & 1.6 \\
Central of SA & 79.6 & 1.9 & 905.78 & 1.7 & 18.7 & 1.2 \\
Southern of SA & 90.1 & 1.7 & 3120.12 & 1.9 & 20.3 & 1.5 \\
West of SA & 86.5 & 1.9 & 3047.56 & 1.6 & 20.1 & 1.4 \\
\hline
\end{tabular}

Source: Computed from World Bank WDI Database, 2018.

Therefore, $\frac{\partial R G P C G_{i t}}{\partial E D_{i t}}=\alpha_{3}+2 \alpha_{4} E D_{i t}$

It gives:

$$
E D^{*}=\frac{-\alpha_{3}}{2 \alpha_{4}}>0
$$

Equation (4) gives the Critical Diversification Index that will be calculated if there is confirmation of a non-linear correlation between variables of this study. It can be exposed that the second-order condition is fulfilled in the optimization course above.

$$
\text { Hence, } \frac{\partial^{2} R G P C G_{i t}}{\partial E D_{i t}^{2}}=2 \alpha_{4}<0
$$

The export diversification index is dignified by the Absolute Deviation of Country Commodity Shares, which UNCTAD extensively uses. It measures the degree of difference between the trade structures of a specific country and the world average. The index signals whether the structure of exports of a given country or group of countries differs from the world's export structure. The following formula gives it:

$$
E D_{J}=\frac{\sum_{1}\left|h_{i j}\right|-\left|h_{1}\right|}{2}
$$

where $h_{i j}$ represent the share of commodity, $i$ is entire exports of country $j$ and $h_{i}$ represents the share of product $i$ in world exports. The diversification index varies from 0 to 1 , skimpy the extent of the differences between the trade structure of the nation or country group and the world average. The index values closer to 1 designate a bigger difference from the world average.

\subsection{Estimation Technique}

The ordinary least square (OLS) technique was used in getting the professed endogeneity connected with the model for experiential estimation.

Numerous other estimation techniques could be used in the existence of endogeneity, but the dynamic panel model is the greatest predictable by the General Method of Moments (GMM) estimation methods. The dynamic panel is challenged with the dynamic panel prejudice tricky. In the occurrence of dynamic 
panel favoritism, estimations by Ordinary Least Squares (OLS) produce unpredictable and positive partialities as the wrapped dependent variable show a relationship with the error margin. The differenced equation is of the form:

$$
\gamma_{i t}-\gamma_{i, t-1}=\alpha_{1}\left(\gamma_{i, t-1}-\gamma_{i, t-2}\right)+\alpha_{2}\left(x_{i t}-x_{i, t-1}\right)+v_{i t}-v_{i, t-1}
$$

As specified previously, Equation (4) eliminates the unnoticed country-specific outcome by pleasing the first differences of Equation (1); thus, undertaking the discrepancy and partialities subsequent from the endogeneity of the explanatory variables by wrapped principles of the endogenous explanatory variables as gadgets. The differenced GMM technique is based on the ensuing moment circumstances under the patterns that the regressors are feebly exogenous, and the error margin is not successively interrelated.

$$
\begin{aligned}
& E\left[\gamma_{i, t-1} \cdot\left(v_{i t}-v_{i, t-1}\right)\right]=0, \text { for } t=3,4, \cdots, T \\
& E\left[x_{i, t-1} \cdot\left(v_{i t}-v_{i, t-1}\right)\right]=0, \text { for } t=3,4, \cdots, T
\end{aligned}
$$

The differenced GMM is not deprived of numerical and theoretical inadequacies. In the first place, the time-invariant country-specific belongings may be of attention in the approximation technique.

Lag differences appliance the endogenous variables in the level equation. The insulated differences and the country-specific secure effects are uncorrelated. The supplementary moment circumstances are stated underneath:

$$
\begin{aligned}
& E\left[\left(\gamma_{i, t-1}-\gamma_{i, t-2}\right) \cdot\left(\mu_{i}-v_{i t}\right)\right]=0, \text { for } t=3,4, \cdots, T \\
& E\left[\left(x_{i, t-1}-x_{i, t-2}\right) \cdot\left(\mu_{i}-v_{i t}\right)\right]=0, \text { for } t=3,4, \cdots, T
\end{aligned}
$$

\section{- Endogeneity}

The Equation (2) detailed above could agonize after endogeneity because endogeneity when there happened by relationship between any of the random error term and the explanatory variables. This spectacle may happen as a result of misplaced variable bias, dimension error, or reverse connection. Then, in the occurrence of endogeneity, $\operatorname{Cov}\left(\mu_{i}, x_{i t}\right) \neq 0$ where $\mu_{i}$ represents the time-invariant country-specific effect, and $x_{i t}$ stand for set of explanatory variables.

\section{- Autocorrelation and Heteroscedasticitys}

The dynamic panel model is recognized to be related with two core bases of perseverance over time. The dependent variable is a function of a constituent of the error term; then its interval is also a purpose of the error term. Pleasing a lag of Equation (2) provides the underneath equation:

$$
\gamma_{i, t-1}=\alpha \gamma_{i, t-2}+x_{i, t-2} \beta+\mu_{i}+v_{i, t-1}
$$

From Equations (3) and (11), noticed the dependent variable and its gap are both functions of the country-specific time-invariant component of the error term.

That is: $y_{i t}=f\left(\mu_{i}\right)$ and $y_{i, t-1}=f\left(\mu_{i}\right)$. It means that the wrapped dependent variable is interrelated with the error term from the model. The dynamic 
panel model is then connected with the problem of autocorrelation.

\section{- Fixed Effects (FE) against Random Effects (RE)}

Here two different molds are made concerning the relationship between the time-invariant error term $\left(\mu_{i}\right)$ and the explanatory variables. These expectations result in the Fixed Effects (FE) and Random Effect (RE) models.

Thus, $\operatorname{Cov}\left(\mu_{i}, x_{i t}\right)=0$

\section{- Unit Root Test}

Even if the Unit Root tricky is typically observed as a time sequence problem, directing unit root tests in panel datasets might be very suitable to certify that the variables under study are motionless, thus dodging the trap of false regressions which relates to the occurrence of dissimilar regressions (Güriş, 2019). The Fisher test was applied in this study.

\section{- Other Diagnostic Tests}

For ensuring dependable estimations from the GMM, convinced vital situations have to be pleased.

Relatively to utmost preceding empirically, this study considered the time series differences in the data, captures the ignored country-specific time-invariant effects, allows for the presence of the wrapped real GDP per capita an explanatory variable, and also panels for endogeneity in the estimation model. The argument of the results developing from the estimations by the GMM method as presented in the data analysis too.

\section{Data Analysis}

This part offers the assessment and discussion of the results. Stata version 12 (STATA 12) was cast-off for computing the empirical estimations.

The descriptive statistics about fifteen (16) SADC nations. The concerning statistics are the standard deviation, the mean, maximum and the minimum values (see Table 2).

During the period 1998-2018, this estimation was computed based on the average real GDP per capita of SADC. Concerning real GDP per capita growth, the region logged an average of 2.9 percentage of growth.

Table 2. Descriptive statistics of real GDP per capita (Growth) and its determinants, 1998-2018.

\begin{tabular}{ccccc}
\hline Variables & $\mu$ & $\sigma$ & Min & Max \\
\hline Real GDPG (Annual \%) & 2.9 & 7.6 & -35.4 & 94.6. \\
Gross Fixed Capital Formation (\% GDP) & 22.3 & 12.1 & 2.0 & 115.1 \\
Export Diversification index & 0.82 & 0.08 & 0.41 & 0.96 \\
Physical Domestic Capital (\%) & 23.2 & 21.7 & 3.6 & 117.8 \\
Political stability & 3.8 & 1.1 & 1.2 & 9.8 \\
Enrolment (Gross secondary school \%) & 39.2 & 26.7 & 4.6 & 126.8 \\
FDI (Net inflows \% GDP) & 6.3 & 13.3 & 59.9 & 148.7 \\
\hline
\end{tabular}

Source: Authors' computation by STATA 12. 
The table above reveals that some nation logged negative growth rates whereas others performed well. A perilous appearance at the data illustrates that such nations as DR Congo, Zimbabwe, and Tanzania achieved below the local average. In contrast, Nations like South Africa and Mozambique implemented fairly overhead of the regional regular period.

The export product diversification index for the region is 0.82 , representing that, SADC countries are gradually enhancing their efforts at exports diversification. This performance is accredited to an increase in primary exports, which may cause less improvements to nations in the South African region than industrial exports.

The average of human capital is $39.2 \%$, the regular net foreign direct investment which represents a GDP is $6.3 \%$, the minimum is $59.9 \%$ and maximum is $148.7 \%$. This indicates that an extensive difference gap exists amongst SADC countries regarding FDI inflows. Normal Political stability in SADC is $3.8 \%$.

\section{- Diagnostic Tests}

Diagnostic tests are steered for endogeneity, autocorrelation, Heteroscedasticity, over-identifying limitations, and the choice of fixed or random-effects models. Each perspective is analyzed in the ensuing sub-sections. The core purpose of this analysis is to make sure the fitness of the model, the validity and reliability of results from the system GMM estimations.

\section{- Endogeneity test}

DWH test was used to confirm the occurrence of endogeneity amongst some of the variables. The Durbin-Wu-Hausman (DWH) test results illustrates that IRGDP per capita and EDS are correlated with the error term as presented in Table 3. It indicates that the fitness of the model by system GMM approach consistency and efficiency.

\section{- Heteroscedasticity}

The existence of Heteroscedasticity was tested by The Breusch-Pagan/CookWeisberg test and the null hypothesis were rejected at the 5 percent level of significance, by this means approving the occurrence of Heteroscedasticity (see Table 4). The system GMM method is developed to yield reliable and fair estimates even if the Heteroscedasticity is appeared.

Table 3. Durbin-Wu-Hausman (DWH) test for endogeneity.

\begin{tabular}{|c|c|}
\hline Null hypothesis & P-value $($ Prob $>\chi)$ \\
\hline IRGDP Per Capita is uncorrelated with the error term. & 0.002 \\
\hline Export Diversification is not correlated with the error term. & 0.023 \\
\hline Export diversification Squared is correlated with the error term. & 0.003 \\
\hline Physical Domestic Capital is uncorrelated with the error term. & 0.012 \\
\hline FDI is uncorrelated with the error term. & 0.011 \\
\hline Human Capital is uncorrelated with the error term. & 0.005 \\
\hline Political stability is uncorrelated with the error term. & 0.004 \\
\hline
\end{tabular}

Source: Authors' Computation Using STATA 12. Note: The residuals of the variables are forecasted and tested for significance after regressing them on all the other exogenous variables. 
Table 4. Breusch-Pagan/Cook-Weisberg test for heteroscedasticity.

$$
\begin{gathered}
\mathrm{H}_{0} \text { : Constant variance } \\
\mathrm{X}(6)=5.82 \\
\text { Prob }>\chi=0.0173
\end{gathered}
$$

Source: Authors' Computation Using STATA 12.

\section{- Fixed and Random Effects (FRE) test}

Results from the Hausman test (Table 5) endorse the suitability of the fixed effects model by refusing the null hypothesis that favors the random-effects model at the 5 percent level of significance. The system GMM estimation technique can hence be practical to the model as it needs a model that fits fixed effects to offer reliable estimates.

The previous diagnostic test marks indicate that the system GMM approximation method is suitable for the approximations and its estimates.

\section{- Unit Root Test}

The null hypothesis that all the panels comprise unit roots is rejected by all the four tests (see Table 6). Choi (2001), stated that when the amount of panels is limited, the inverse chi-squared test turn out to be a very proper and influential tool for testing unit roots.

\section{- System GMM Estimations}

The first regression model comprises all the explanatory variables except the regional dummies and the interacted variables. In the second regression model, we added the regional dummies to the first model variables; in the third regression model, we introduce the interrelated variables with the four regional dummies (ED*MDUMMY, ED*SDUMMY, and ED*WDUMMY) into the model collected with the other explanatory variables. These regional dummies, the terms squared of export diversification and export diversification are not included in the third regression model because they show severe collinearity with the interrelated variables

In Table 4, the explanatory variables are jointly significant as illustrated by Wald Chi-squared for all the regressions. The Arellano-Bond test AR (2) in the first alterations miscarries to cast-off the null hypothesis.

Similarly, the Sargan test for over-identifying limitations shows that the over-identifying-limitations are valid in the model; therefore, the model is not weakened by too many instruments.

\section{Results and Discussions}

The correlation between real GDP per capita and the explanatory variables, with export diversification, is discussed below.

In toeing the line with a priori prospects, the coefficient of export diversification (ED) is positive. The coefficients of export diversification in regression models (1) and (2) propose that a percentage upsurge in the export diversification index of a country in SADC will reason more growth about 1 percent and 
Table 5. Hausman test for fixed versus random effects.

Ho: Difference in coefficients not systematic (there is a random effect)

$$
\begin{gathered}
\chi(6)=(b-B)^{\prime}\left[\left(V_{b}-V_{B}\right)^{(1)}\right](b-B)=17.03 \\
\text { Prob }>\chi=0.0137
\end{gathered}
$$

Source: Authors' Computation Using STATA 12.

Table 6. Fisher-Type stationarity (Unit Root) test.

\begin{tabular}{ccccccccc}
\hline Variable & \multicolumn{2}{c}{$\begin{array}{c}\text { Inverse } \\
\text { Chi-squared }\end{array}$} & Inverse Normal & Inverse Logit t & $\begin{array}{c}\text { Mod inv. } \\
\text { Chi-squared }\end{array}$ \\
& Statistic & Prob & Statistic & Prob & Statistic & Prob & Statistic & Prob \\
\hline GDP/Capita Growth & 289.460 & 0.000 & -11.374 & 0.000 & -12.373 & 0.000 & 15.667 & 0.000 \\
PDC & 192.362 & 0.000 & -6.753 & 0.000 & -6.852 & 0.000 & 8.430 & 0.000 \\
Export & 247.788 & 0.000 & -9.236 & 0.000 & -9.236 & 0.000 & 12.232 & 0.000 \\
Diversification & & & & & & & & \\
EDS & 243.563 & 0.000 & -9.342 & 0.000 & -9.362 & 0.000 & 12.261 & 0.000 \\
Human Capital & 298.192 & 0.000 & -10.432 & 0.000 & -11.432 & 0.000 & 16.428 & 0.000 \\
Political stability & 63.632 & 0.078 & -0.921 & 0.058 & -0.981 & 0.049 & 1.382 & 0.069 \\
FDI & 249.320 & 0.000 & -9.519 & 0.000 & -9.919 & 0.000 & 12.812 & 0.000 \\
\hline
\end{tabular}

Source: Authors' Computation Using STATA 12.

1.8, respectively. This result advises that for Southern Africa nations with higher levels of export diversification are credible to know faster growth than others with export diversification at low levels.

Due to the present findings, the coefficient of the squared term of export diversification is least significant in the regression models. It means that nations in SADC can strengthen export diversification to reach higher growth. The regional dummies are announced in model (2). With exemption to the South-West Africa dummy, the coefficients of the regional dummies show that the explanatory variables' cumulative growth effect differs across the sub-regions of SADC. The regression model (2) observed in Table 4 that the total growth effect of the explanatory variables is lower for South-Central and Southern Africa countries compared to countries in South-East Africa. However, the South-West Africa dummy's coefficient is insignificant, suggesting that there is no significant between South-West and South-East Africa nations in terms of the total growth effects of the explanatory variables.

It is perceived from the Table 4 that the coefficient of the initial real GDP per capita is negative and statistically founded to be significant at 1 percent in the model (2). It indicates that nations with lesser initial real GDP per capita tend to grow faster than those with higher initial real GDP per capita. This result is in the same line with the convergence theory, which forecast that countries' income 
per capita would meet over time. It also approves that findings of other previous studies that are Hesse (2009) and (Pastor, Peraita, Serrano, \& Soler, 2018). They find a negative correlation between real GDP per capita growth and initial real GDP per capita.

The increased Solow growth model expects a positive correlation between physical capital and economic growth. This expectation is established by the positive and significant coefficient of gross fixed capital formation in the first regression model (see Table 7).

Table 7. System GMM estimations based on the augmented Solow growth model.

\begin{tabular}{|c|c|c|c|}
\hline \multirow{2}{*}{ Variables } & \multicolumn{3}{|c|}{ Regression Model } \\
\hline & 1 & 2 & 3 \\
\hline IRGDP Per Capita (Constant 2000\$) & $0.23(0.017)$ & $-0.04^{\star * *}(0.023)$ & $-0.02^{\star *}(0.008)$ \\
\hline Gross Fixed Capital Formation & $0.336^{* * *}(0.053)$ & $-0.148(0.301)$ & $0.022(0.149)$ \\
\hline Export Diversification (ED) & $1.026^{* * *}(0.277)$ & $1.770^{\star * *}(0.491)$ & \\
\hline Export diversification Squared & $-0.293(0.179)$ & $0.017(0.288)$ & \\
\hline Physical Domestic Capital & $0.126^{\star *}(0.085)$ & $0.746(0.176)$ & $-0.437(0.138)$ \\
\hline FDI (Net inflows \% GDP) & $0.020(0.032)$ & $0.048(0.45)$ & $-0.007(0.038)$ \\
\hline Human Capital & $0.166^{\star * *}(0042)$ & $1.008^{\star * *}(0.253)$ & $0.553^{\star * *}(0.126)$ \\
\hline Political stability & $0.126^{\star * *}(0012)$ & $1.006^{\star * *}(0.151)$ & $0.452^{\star * \star}(0.103)$ \\
\hline Eastern-SADC Dummy (EDUMMY) & & $-0.088^{\star * *}(0.266)$ & \\
\hline Central-SADC Dummy (CDUMMY) & & $-0.232^{\star * \star}(0.363)$ & \\
\hline Southern-SADC Dummy (SDUMMY) & & $0.403(0.254)$ & \\
\hline Western-SADC Dummy (WDUMMY) & & $-0.272^{\star \star \star}(0.412)$ & \\
\hline ED*EDUMMY & & & $0.615^{\star * *}(1.092)$ \\
\hline $\mathrm{ED}^{\star} \mathrm{CDUMMY}$ & & & $0.515^{\star * *}(0.292)$ \\
\hline ED*SDUMMY & & & $-1.615^{\star * *}(1.072)$ \\
\hline $\mathrm{ED}^{* W D U M M Y}$ & & & $0.518^{\star * *}(0.574)$ \\
\hline Wald Chi-squared (Prob > Chi-Squares) & 0.000 & 0.000 & 0.000 \\
\hline Number of observations & 228 & 228 & 228 \\
\hline Arellano-Bond [AR (2). Prob > Z] & 0.376 & 0.770 & 0.821 \\
\hline Sargan test (Prob $>$ Chi-Squared) & 0.377 & 0.629 & 0.902 \\
\hline
\end{tabular}

Source: Authors' computation by STATA 12. Note: Note: The dependent variable is real GDP per capita growth. Figures in regression are the estimations' standard errors, and ${ }^{* *}$, ${ }^{* *}$, and ${ }^{*}$ refer to the statistical significance of the estimations at $1 \%, 5 \%$, and $10 \%$ disparately. The dependent variable is the log of GDP per capita growth. But not for the dummies; all the other variables are in logs. 
The correlation between political stability and economic growth is indisputable. Economic growth in a country depends on the development strategies created and implemented by its political system (Corovei \& Socol, 2019; Yakubu et al., 2020). A country's political system is accurate in determining its fate. Political stability is an essential element for economic growth because it enhances productivity and human and physical resources necessary for development. On the other hand, political stability is also found to have a significant effect on economic growth in SADC. It means that most of the countries in Southern Africa are not stable politically; this yields a negative effect on economic growth.

\section{Conclusion}

To empirically inaugurate a correlation between export diversification and economic growth, the model for approximation is stated from the dynamic panel growth framework centered on the expectations of the human capital increased Solow model and assessed using the system GMM estimation method. The approximation results show a positive correlation between export diversification and economic growth in SADC. And it satisfies the objectives of the study. However, the results do not illustrate evidence of a hump-shaped (non-monotonic) relationship between export diversification and economic growth. To inspire more diversification, the paper suggested to the governments in SADC to implement entrepreneurship sustenance schemes and create a satisfactory investment climate to cheer investment in new production sectors and increase current sectors for exports.

\section{Acknowledgements}

Our thanks go to Professor Zhang Yan of Hefei University of Technology who read and approved the final manuscript.

\section{Conflicts of Interest}

The authors declare no conflicts of interest regarding the publication of this paper.

\section{References}

Arip, M. A., Yee, L. S., \& Abdul Karim, B. (2010). Export Diversification and Economic growth in Malaysia. MPRA Paper No. 20588. University Library of Munich.

Cadot, O., Carrère, C., \& Strauss-Kahn, V. (2011). Export Diversification: What's behind the Hump? Review of Economics and Statistics, 93, 590-605. https://doi.org/10.1162/REST a 00078

Cook, N. P., \& Jones, J. C. (2015). The African Growth and Opportunity Act (AGOA) and Export Diversification. The Journal of International Trade \& Economic Development, 24, 947-967. https://doi.org/10.1080/09638199.2014.986663

Corovei, E. A., \& Socol, A. (2019). The Impact of Political Stability on Economic Growth in European Union. Ovidius University Annals, Economic Sciences Series, No. 1, 8-14.

Choi, I. (2001). Unit Root Tests for Panel Data. Journal of International Money and 
Finance, 20, 249-272.

Garcia, F. J., Ciko, L., Gaurav, A., \& Hough, K. (2015). Reforming the International Investment Regime: Lessons from International Trade Law. Journal of International Economic Law, 18, 861-892. https://doi.org/10.1093/jiel/igv042

Güriş, B. (2019). A New Nonlinear Unit Root Test with Fourier Function. Communications in Statistics-Simulation and Computation, 48, 3056-3062. https://doi.org/10.1080/03610918.2018.1473591

Hamed, K., Hadi, D., \& Hossein, K. (2014). Export Diversification and Economic Growth in Some Selected Developing Countries. African Journal of Business Management, 8, 700-704. https://doi.org/10.5897/AJBM2012.397

Han, J.-S., \& Lee, J.-W. (2020). Demographic Change, Human Capital, and Economic Growth in Korea. Japan and the World Economy, 53, Article ID: 100984. https://doi.org/10.1016/j.japwor.2019.100984

Hesse, H. (2009). Export Diversification and Economic Growth. In R. Newfarmer, W. Shaw, \& P. Walkenhorst (Eds.), Breaking into New Markets: Emerging Lessons for Export Diversification (pp. 55-80). The World Bank.

Iizuka, M., \& Gebreeyesus, M. (2017). Using Functions of Innovation Systems to Understand the Successful Emergence of Non-Traditional Agricultural Export Industries in Developing Countries: Cases from Ethiopia and Chile. The European Journal of Development Research, 29, 384-403. https://doi.org/10.1057/s41287-016-0004-0

Jütting, J. P., Kauffmann, C., McDonnell, I., Osterrieder, H., Pinaud, N., \& Wegner, L. (2004). Decentralization and Poverty in Developing Countries: Exploring the Impact. SSRN Electronic Journal. https://doi.org/10.2139/ssrn.583762

Kahiya, E. T., \& Dean, D. L. (2016). Export Stages and Export Barriers: Revisiting Traditional Export Development. Thunderbird International Business Review, 58, 75-89. https://doi.org/10.1002/tie.21741

Kalayci, S. (2019). Comparing the Balance of Payments of Northern and Southern European Countries in Terms of Heckscher Ohlin Theory. Economics and Politics, Academician Publishing House.

Liu, H., Kim, H., Liang, S., \& Kwon, O.-S. (2018). Export Diversification and Ecological Footprint: A Comparative Study on EKC Theory among Korea, Japan, and China. Sustainability, 10, Article No. 3657. https://doi.org/10.3390/su10103657

McNown, R., Sam, C. Y., \& Goh, S. K. (2018). Bootstrapping the Autoregressive Distributed Lag Test for Cointegration. Applied Economics, 50, 1509-1521. https://doi.org/10.1080/00036846.2017.1366643

Pastor, J. M., Peraita, C., Serrano, L., \& Soler, Á. (2018). Higher Education Institutions, Economic Growth and GDP Per Capita in European Union Countries. European Planning Studies, 26, 1616-1637. https://doi.org/10.1080/09654313.2018.1480707

Robinson, L. A., Hammitt, J. K., Chang, A. Y., \& Resch, S. (2017). Understanding and Improving the One and Three Times GDP Per Capita Cost-Effectiveness Thresholds. Health Policy and Planning, 32, 141-145. https://doi.org/10.1093/heapol/czw096

Ross, M. L. (2019). What Do We Know about Export Diversification in Oil-Producing Countries? The Extractive Industries and Society, 6, 792-806. https://doi.org/10.1016/j.exis.2019.06.004

Umarxodjaeva, M. G., \& Sadriddinova, N. X. Q. (2019). Export Potential Development and Export Diversification of Fruit and Vegetable Products in Uzbekistans Economy. International Journal of Research in Management \& Business Studies, 6, 35-37.

Wang, L., Chang, H.-L., Rizvi, S. K. A., \& Sari, A. (2020). Are Eco-Innovation and Export 
Diversification Mutually Exclusive to Control Carbon Emissions in G-7 Countries? Journal of Environmental Management, 270, Article ID: 110829. https://doi.org/10.1016/j.jenvman.2020.110829

Williams, R., Allison, P. D., \& Moral-Benito, E. (2018). Linear Dynamic Panel-Data Estimation Using Maximum Likelihood and Structural equation Modeling. The Stata Journal, 18, 293-326. https://doi.org/10.1177\%2F1536867X1801800201

Yakubu, Z., Loganathan, N., Mursitama, T. N., Mardani, A., Khan, S. A. R., \& Hassan, A. A. G. (2020). Financial Liberalisation, Political Stability, and Economic Determinants of Real Economic Growth in Kenya. Energies, 13, Article No. 3426. https://doi.org/10.3390/en13133426

Yokoyama, K., \& Alemu, A. (2009). The Impacts of Vertical and Horizontal Export Diversification on Growth between Sub-Saharan Africa and East Asia's Performances. Ritsumeikan International Affairs, 7, 49-90. 